\title{
Metabolic Properties of Fibers and Connective Tissue of Four Muscles from Bovine Carcasses
}

\author{
Marie-Pierre Ellies-Oury ${ }^{1,2,3}{ }^{*}$, Rollande Dumont ${ }^{4}$, Didier Micol2,3, Yves Durand5, \\ Brigitte Picard ${ }^{2,3}$ \\ ${ }^{1}$ Bordeaux Sciences Agro, Gradignan Cedex, France \\ ${ }^{2}$ Institut National de la Recherche Agronomique, St-Genès-Champanelle, France \\ ${ }^{3}$ Clermont Université, VetAgro Sup, UMR1213 Herbivores, Clermont-Ferrand, France \\ ${ }^{4}$ AgroSup Dijon, Dijon Cedex, France \\ ${ }^{5}$ Institut Charolais, Centre Europe Atlantique, Charolles, France \\ Email: *marie-pierre.ellies@clermont.inra.fr
}

Received 25 September 2015; accepted 11 December 2015; published 14 December 2015

Copyright (C) 2015 by authors and Scientific Research Publishing Inc.

This work is licensed under the Creative Commons Attribution International License (CC BY).

http://creativecommons.org/licenses/by/4.0/

c) (i) Open Access

\begin{abstract}
Meat-grain-size (MGS) assessment is an empirical method for the early prediction of meat quality, a larger grain being synonymous with higher meat tenderness. The objective was to characterize 4 muscles (longissimus thoracis LT; rectus abdominis RA; longus colli LC; diaphragma D) of 5 coarse and 5 fine carcasses in terms of MGS in order to establish a link between muscular physicochemical properties and carcass MGS score. All comparisons were made of samples with similar fat content. The broiled sample hardness (shear force) was significantly higher for the coarse group than for the fine group (7.20 vs $5.89 \mathrm{~kg}$; RA). Higher collagen content (27.94 vs $24.87 \mathrm{mg} / \mathrm{g}$ of dry matter in LT muscle; $15.86 \mathrm{vs} 13.13 \mathrm{mg} / \mathrm{g}$ of dry matter in D muscle), higher oxidative metabolism (cytochrome-c oxidase; LT and D) but also higher glycolytic metabolism (lactate dehydrogenase; LT) were also observed in the coarse groups. Not all the muscles react in a similar way depending on the MGS group. Nevertheless, significant results are constant from one muscle to another, the RA being the only muscle for which the difference in hardness between the two groups is significant.
\end{abstract}

\section{Keywords}

Meat Grain, Tenderness, Muscles, Collagen, Bovine

\footnotetext{
"Corresponding author.
}

How to cite this paper: Ellies-Oury, M.-P., Dumont, R., Micol, D., Durand, Y. and Picard, B. (2015) Metabolic Properties of Fibers and Connective Tissue of Four Muscles from Bovine Carcasses. Food and Nutrition Sciences, 6, 1522-1532. 


\section{Introduction}

Beef wholesalers and butchers are very interested in predicting meat quality traits in order to evaluate consumer acceptance of beef. The method involving consumers or trained panels is time-consuming, expensive and impossible on a large scale. Moreover, it is useful to have early knowledge of the meat quality traits of carcasses and this method cannot be used early enough. Early knowledge allows professionals to direct carcasses to the various markets (butchers, mass retailing, hard-discount, etc.) in the most appropriate way. For this reason, the beef industry is currently attempting to distinguish between standard and high-quality beef products sold by both supermarkets and butchers mainly on the basis of tenderness rather than flavor and taste. This is partly founded on the assumption that butchers possess a know-how which allows them to classify the carcasses according to their expected quality early on.

Carcass classifications of meat quality are integrated into many French specifications so that carcasses can be approved or rejected depending on their expected quality. This is all the more important since many surveys have already shown that the lack of consistency in meat quality is the principal reason for consumers to stop purchasing beef [1]. On the other hand, it seems that many consumers may be ready to pay more for beef if the meat quality, especially tenderness, can be guaranteed [2]. Some butchers have know-how that is founded on subjective criteria used to judge the expected tenderness of carcasses. This know-how calls on a property of the meat which is called "grain of meat". Previously, Hammond [3] indicated that there was no correlation between grain size and tenderness, but that coarse grain size led to less palatable and "stringy" meat. A preliminary ethnological study [4] based on the analysis of expert opinions revealed that the notion of "meat grain" was positive and had become confused with that of tenderness.

Meat grain size corresponds to the observable network on a cross section of muscle and also includes the distribution of the perimysium, the diameter of the muscular fibers and the extra-cellular matrix which surrounds them [5] [6]. According to Purslow [6], the "grain of meat" is easily discerned by the eye, and is described as the division of muscles into fascicles. This notion of "grain of meat" was included in a review of the history of sensory evaluation of meat by Szczesniak [7] and had also been used in the USDA grading scheme for beef for many decades with fine grain being a requirement for the top grades. Nevertheless, much of the work on muscle grain and meat texture cited in the literature is 40 - 70 years old and therefore did not appear in modern databases.

With regard to knowledge and know-how, a preliminary in-depth analysis of beef retailer and butcher discourses on grain of meat expression was conducted [4], and led to a definition of this term and the identification of some "meat markers" that could be used to estimate grain of meat for the entire carcass and after the separation of fore and hindquarters. The ethnological study [4] [8] indicated that "grain-of-meat" evaluation might be obtained by associating various senses such as touch, sight, but also texture evaluation. It is useful to quantify the variability of muscle characteristics in relation to meat quality traits evaluated by scoring the meat grain size of the carcasses. However, it is essential to specify the terms as "fine" grain has previously been associated with different characteristics: texture for Brady [9] or grain size for Hammond [3]. Hammond [3] uses "fine" to describe small grain, i.e. small bundle or fascicle size. Five years later, Brady [9] uses the term "fine" to indicate the most desirable texture, the finest texture actually being the largest grain size. So although Brady and Hammond associated "fine texture" with tenderness, they meant opposite things by the word "fine". That was why an in-depth study was carried out further to the ethnological work in order to establish a marking grid for the grain of meat. In this way, some of the markers among those identified in the ethnological study were formalized and integrated into a scale (Table 1) and associated with a written and/or a photographic definition. The finest grain was obtained in the well-shaped and well-balanced carcass, with a really round thigh, large muscle thickness, limited marbling, a M. longissimus thoracis without nerves and smooth and soft to the touch, in accordance with a statistical analysis of data [10] [11]. According to the operators of the French Charolais beef industry, four muscles can provide information about the meat grain size of a carcass: M. longissimus thoracis, rectus abdominis, longus colli and diaphragma [11]. The M. longissimus thoracis for which numerous results are available is often considered to be a reference. Its removal is difficult to carry out and brings about significant depreciation whereas M. rectus abdominis, longus colli and diaphragma are easier to sample without excessive depreciation of the value of the carcass. The variability between the contractile and metabolic properties of muscles is high. The permanently active muscles such as M. diaphragma, the heart or M. masseter have a more oxidative metabolism than less active muscles such as M. longus colli. The physicochemical properties of one muscle are difficult to 
Table 1. Criteria scored for the whole carcass and after the separation of quarters to assess "grain of meat".

\begin{tabular}{ccc}
\hline \multicolumn{1}{c}{ Carcass assessment relative to evaluation of the whole carcass } & $\begin{array}{c}\text { Score } \mathbf{*} \\
\text { (coarse grain of meat) }\end{array}$ & $\begin{array}{c}\text { Score of } \mathbf{5}^{*} \\
\text { (fine grain of meat) }\end{array}$ \\
\hline Carcass assessment & big and hollow & plump and well conformed \\
Balance between hind and forequarters & bad balance, too much forequarters & good balance, little forequarters \\
Thigh conformation & thigh without round & round and regular thigh \\
Bone development & unrefined, too developed & fine \\
Fat development & thin or very fat carcass & covered carcass \\
Feel of the diaphragma & hard and dry fibres & crushing and flexible fibres \\
Feel of the longus colli & hard and dry fibres & crushing and flexible fibres \\
\hline
\end{tabular}

Carcass assessment relative to evaluation after separation of quarters

Muscle relative depth

Inter-muscular fat at the $5^{\text {th }}$ rib level

Longissimus thoracis seepage

Longissimus thoracis nerves

Longissimus thoracis marbling

Longissimus thoracis fibres

Evaluation by touching the longissimus thoracis and of the rhomboideus thoracis no muscle depth, high fat depth

large amount

dry with small pearls

many visible nerves

visible and poorly distributed marbling

easily visible to the neck eye

rough and granular large muscle depth, light fat depth

limited fat development

neither very wet, nor very dry

lack of visible nerves

evenly distributed or invisible marbling

very fine, not visible

smooth and soft, without harshness

Global "grain of meat" assessment

Very rough/granular

Smooth, soft, without harshness

*Each criterion is scored between 1 and 5 ; the score of 1 being the least favorable for "grain of meat" and the score of 5 being the most favorable.

extrapolate to another muscles of the carcass. The choice was made to work on the four muscles instead of just one. Although the physicochemical properties of the various muscles of a carcass present a high proportion of similarity (70\% similarity between M. rectus abdominis and M. longissimus thoracis) [12], it is difficult to extrapolate from one muscle to another. M. diaphragma and longus colli and, to a lesser extent, M. rectus abdominis have not been studied often. The primary aim of this project was to characterize the above-mentioned four muscles of the carcass (M. longissimus thoracis, rectus abdominis, longus colli and diaphragm) and to establish links between their properties and the meat grain score attributed to the carcass.

\section{Materials and Methods}

\subsection{Animal and Carcass Measurements}

The study concerned the M. rectus abdominis, longissimus thoracis, longus colli and diaphragma of 10 Charolais heifers. Heifers were slaughtered on average at the age of 35 months with a carcass weight of $405 \mathrm{~kg}$. All the carcasses chosen scored 3 on the European scale of fat development. This study was conducted in an industrial slaughterhouse and required no ethical approval.

The muscles were removed 24 hours post mortem from non-electrically stimulated carcasses. The meat grain size score was recorded just before removal, following a meat grain scale (Table 1). The assessment of the whole carcass was carried out by 4 experts who were regular users of this approach at least 24 hours post mortem. Seven criteria were scored between 1 and 5 (with no half-points). The assessment was carried out on the forequarter after separation of quarters, at the level of the $5^{\text {th }}$ rib, 48 hours post mortem. Eight criteria were scored between 1 and 5 (with no half points). For each criterion, the score of 5 was attributed to the modality most favourable to the "grain of meat" according to the experts (Table 1). It had previously been confirmed that scores given for each of the 15 criteria were in line with the global score given to "grain of meat" and that the touch evaluation of each of the 4 muscles was equivalent for a given carcass [10] [11]. To select the 10 carcasses 
with extreme grain of meat scores, a total of 60 heifer carcasses were scored by 4 experts familiar with "grain of meat" evaluation at the commercial slaughterhouse "Charollais Viande" located in Paray-Le-Monial (France). Among these carcasses, we selected the 5 that had the best score and the 5 that had the lowest score for "grain of meat". As no carcasses were scored either 1 out of 5 or 5 out of 5 , we constituted two groups consisting of 10 animals, with a score of either 2 or 4 out of 5 in "grain-of-meat" assessment. The 2 groups were called coarse and fine respectively.

\subsection{Muscle Characteristics}

Muscle characterization was carried out on muscles excised 24 hours after slaughter. All slaughters were performed in the same industrial slaughterhouse in order to standardize slaughtering, chilling and storing procedures. The sampling procedures were standardized for each muscle with a clearly identified sample location. Muscles were removed from the right half-carcass 24 hours post mortem.

The samples of M. rectus abdominis, longissimus thoracis and diaphragma destined for collagen, dry matter and lipid content analysis were vacuum packed, aged at $4^{\circ} \mathrm{C}$ for 14 days post mortem and then frozen. After thawing, three trial groups of $10 \mathrm{~g}$ of muscle were taken for each of the three analyses of dry matter, collagen content and solubility and lipid content. Dry matter content was measured on ground meat by oven drying at $103^{\circ} \mathrm{C}$ for 48 hours. The intramuscular lipid content was determined after hydrolysis with hydrochloric acid and extraction with petroleum ether (boiling point: $35^{\circ} \mathrm{C}$; Soxhlet standard method) [13]. Collagen content was measured by the hydroxyproline content, following the Bergman and Loxley method [14]. Insoluble collagen was determined in accordance with a procedure described by Bonnet and Kopp [15]. Collagen solubility was expressed as a percentage of heat-soluble to total collagen.

The samples of M. rectus abdominis, longissimus thoracis, longus colli and diaphragma intended for characterization of the metabolic properties of the muscles were cut into small fragments, frozen in liquid nitrogen and stored at $-80^{\circ} \mathrm{C}$ before grinding. The metabolic type of the muscles was determined by measuring enzyme activity on 200mg of frozen sample. Anaerobic glycolytic metabolism was assessed by lactate dehydrogenase (LDH) activity [16]. Aerobic oxidative metabolism was assessed by isocitrate dehydrogenase (ICDH) and cytochrome-c oxidase (COX) activities according to Briand et al. [17] and Piot et al. [18] respectively. To confirm the accuracy of each result, each muscle sample was tested in triplicate for each muscular characteristic.

\subsection{Texture Measurements}

The samples of M. rectus abdominis and diaphragma destined for textural measurements on raw and broiled meat were vacuum packed, aged at $4^{\circ} \mathrm{C}$ for 14 days post mortem and then frozen. The frozen samples were maintained at $30^{\circ} \mathrm{C}$ for 20 minutes. Shear force was measured following the Salé method [19] adapted for an MTS Synergie 200 material testing machine. Meat samples were tested raw, or after having being grilled for 1 minute 45 seconds at $300^{\circ} \mathrm{C}$ in order to reach a core temperature of $55^{\circ} \mathrm{C}$ (as measured with a temperature probe). Every muscle sample was cut into core samples with different thickness. For each sample, 25 measurements were carried out in various thicknesses of muscle core samples of between 0.3 and $1.3 \mathrm{~cm}$. Meat samples were cut perpendicularly to fibers. The force-movement diagram obtained presents a peak which corresponds to the maximum shear measured in kilograms. The final value of the maximum shear was calculated by linear regression for a thickness of $1 \mathrm{~cm}$.

The M. longus colli was too thin and too small to evaluate all of the characteristics. Only the enzymatic analyses were performed on it. Likewise, the M. longissimus thoracis removed at the $6^{\text {th }}$ rib did not have enough material to evaluate shear force. Shear force evaluation must be performed on muscles cut parallel to fibers, and this is only feasible on M. longissimus thoracis by taking 2 or 3 different ribs depending on the thickness of the rib. However, it turned out that sampling 2 or 3 ribs caused too great a carcass depreciation for the slaughterhouse, all the more so since the carcasses are of high quality.

\subsection{Statistical Analysis}

Variance analysis and mean multiple comparisons with one factor (the grain score) were carried out. Multiple comparisons of the adjusted means (LSMEANS) were carried out using the PDIFF option of the GLM procedure. Variance analysis used the GLM procedure (general linear model) from SAS 9.1 [20]. 


\section{Results and Discussion}

\subsection{Carcass Characteristics}

Carcasses from the fine group were found to be plumper and better-shaped ( $p=0.01$ ), with a rounder and more regular thigh $(p=0.04)$ than those from the coarse group (Table 2). This resulted in the hypothesis of there being a positive link between muscle development and grain of meat. For many other criteria muscles of carcasses from the fine group obtained better scores than those from the coarse group: M. diaphragma and longus colli of the fine group were found to be more crushable and flexible ( $p=0.02$ and 0.002 respectively). Fewer visible nerves (visible connective tissues) were found on M. longissimus thoracis ( $p=0.005)$. On touch, M. longissimus thoracis was considered to be smoother and softer and with less hardness $(p<0.0001$; Table 2). It is interesting to note that even though carcasses were selected for homogeneous carcass fat development (score of 3 in the EUROP fat development grid), the experts found a significant difference in M. longissimus thoracis marbling scores between the coarse and the fine groups: marbling was found to be more homogeneous on the M. longissimus thoracis of the fine group $(p=0.02)$. The development of fat deposits is indeed different depending on whether it is subcutaneous, abdominal and intermuscular fat (notation EUROP) or intramuscular fat (marbling evaluation).

\subsection{Muscle Characteristics}

Shear force on raw meat is slightly higher in M. diaphragma than in M. rectus abdominis (6.88 and 5.73 vs 5.03 and $4.46 \mathrm{~kg}$; Table 3). However, the difference between these two muscles was not found for broiled meat, with averages equal to 6.35 and $6.54 \mathrm{~kg}$ respectively. These results are similar to those obtained on broiled muscles by Belew et al. [21], who indicated that M. diaphragma is one of the most tender muscles of the carcass (Warner-Bratzler Shear Force $=2.03 \mathrm{~kg}$ ), whereas M. rectus abdominis appears to require a higher Warner-Bratzler shear force to be cut (between 3.2 and $3.9 \mathrm{~kg}$ ). Rheological measurements were not performed on M. longissimus thoracis and longus colli because of high carcass depreciation and muscle smallness. Nevertheless, it has previously been indicated that the M. rectus abdominis is significantly tougher than M. longissimus and semitendinosus [22]. The difference in raw meat shear force between M. diaphragma and M. rectus abdominis could be linked to the total collagen content. Indeed, M. diaphragma was composed of significantly more collagen (26.4 vs $20.4 \mathrm{mg} / \mathrm{g}$ DM on average) with an equivalent solubility to M. rectus abdominis. The difference in shear force between raw and broiled muscles in M. diaphragma and M. rectus abdominis may be linked either to the variation in lipid content between these two muscles or to the way the muscles were cut. The M. diaphragma is twice as rich in lipids as $\mathrm{M}$. rectus abdominis (32.2\% vs $17.2 \% \mathrm{DM}$ on average) and it could be hypothesized that the shear needed to cut fat is lower when fat is diffuse than when fat is raw and compact. Moreover, the M. diaphragma is a muscle in which it is easy to cut homogeneous steaks with cuts parallel to fibers.

Table 2. Scores out of 5 given by the experts for various carcass characteristic for the "grain-of-meat" group.

\begin{tabular}{|c|c|c|c|}
\hline Criteria for grain of meat evaluation (scores on 5) Meat "grain” size & coarse & fine & $p$ \\
\hline $\begin{array}{l}\text { Carcass appreciation } \\
\text { (big and hollow: } 1 / 5 ; \text { plump and well conformed: } 5 / 5 \text { ) }\end{array}$ & $2.5 \pm 0.5^{(1)}$ & $3.3 \pm 0.3$ & 0.01 \\
\hline $\begin{array}{l}\text { Thigh conformation } \\
\text { (thigh without roundness: } 1 / 5 \text {; round and regular thigh: } 5 / 5 \text { ) }\end{array}$ & $2.8 \pm 0.6$ & $3.6 \pm 0.4$ & 0.04 \\
\hline $\begin{array}{l}\text { Assessment by touching the M. diaphragma } \\
\text { (hard and dry fibers: } 1 / 5 \text {; crushing and flexible fibers: } 5 / 5 \text { ) }\end{array}$ & $2.1 \pm 0.2$ & $3.0 \pm 0.6$ & 0.02 \\
\hline $\begin{array}{l}\text { Evaluation by touching the M. longus colli } \\
\text { (hard and dry fibers: } 1 / 5 \text {; crushable and flexible fibers: } 5 / 5 \text { ) }\end{array}$ & $2.3 \pm 0.4$ & $3.5 \pm 0.4$ & 0.002 \\
\hline $\begin{array}{l}\text { Evaluation of the M. longissimus thoracis nerves } \\
\text { (many visible nerves: } 1 / 5 \text {; lack of visible nerves: } 5 / 5 \text { ) }\end{array}$ & $2.7 \pm 0.4$ & $3.8 \pm 0.4$ & 0.005 \\
\hline $\begin{array}{l}\text { Evaluation of the M. longissimus thoracis marbling } \\
\text { (visible and badly distributed marbling: 1/5; homogeneously distributed or invisible marbling: 5/5) }\end{array}$ & $2.7 \pm 0.3$ & $3.6 \pm 0.7$ & 0.02 \\
\hline $\begin{array}{l}\text { Evaluation by touching the M. longissimus thoracis } \\
\text { (rough and granular: 1/5; smooth and soft, without hardness: } 5 / 5 \text { ) }\end{array}$ & $2.1 \pm 0.2$ & $3.8 \pm 0.4$ & 0.0001 \\
\hline
\end{tabular}




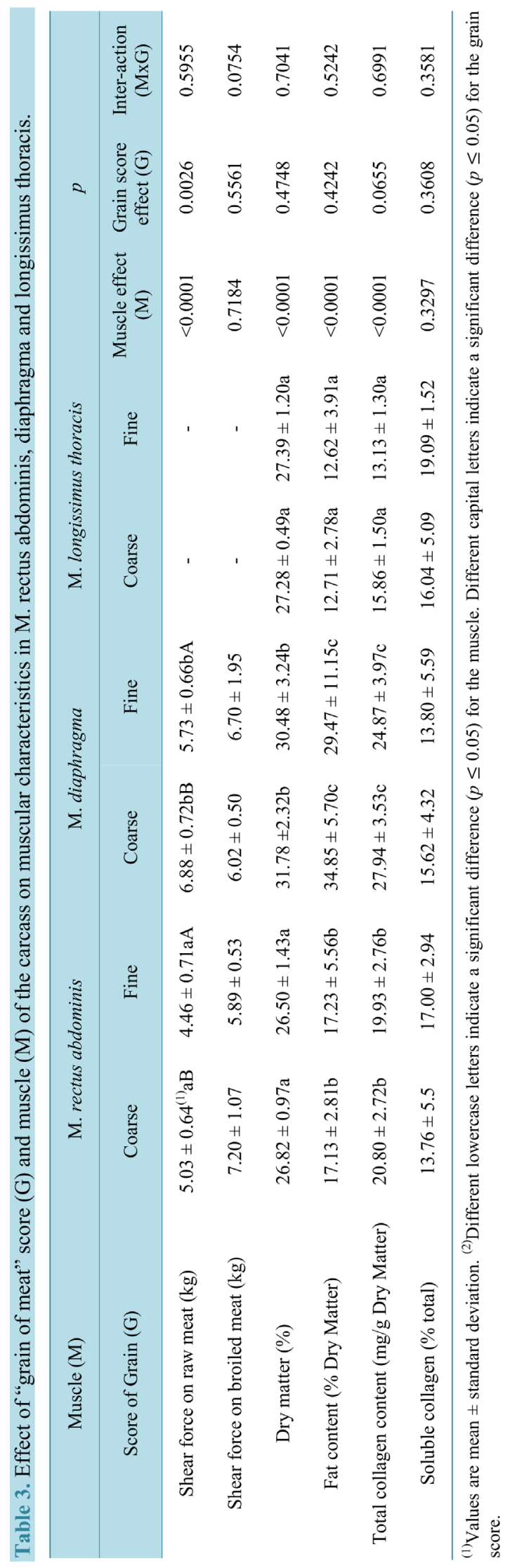


On the contrary, in the M. rectus abdominis, cutting is harder to perform and fibers have to be cut on the bias to achieve homogenous thickness. Thus, it could be hypothesized that the way in which fibers are cut has a significant impact on muscle shrinkage during cooking, leading to excessive hardening of M. rectus abdominis in comparison to M. diaphragma.

These two hypotheses could explain why shear force increases with cooking in M. rectus abdominis and decreases in M. diaphragma but this needs to be confirmed by further analysis. As previously indicated [12], M. longissimus thoracis was composed of significantly less collagen than M. rectus abdominis (14.5 vs $20.4 \mathrm{mg} / \mathrm{g}$ DM on average). The solubility of this collagen was slightly higher in M. longissimus thoracis, but the difference was not significant. M. longissimus thoracis contained slightly less intramuscular fat (12.7\% vs 17.2\% DM on average) than M. rectus abdominis, as previously indicated by Brackebush et al. [23]. However in the present work, the difference between M. rectus abdominis and longissimus thoracis intramuscular fat was not significant. Indeed, lipid content was extremely heterogeneous in the muscles tested, with the M. diaphragma having practically twice the lipid content as M. longissimus thoracis (1.8 times more) and M. rectus abdominis (2.5 times more).

For enzyme activity, M. longissimus thoracis and rectus abdominis appeared more glycolytic than M. diaphragma and longus colli (573 and 549 vs 306 and $357 \mu \mathrm{mol} / \mathrm{min} / \mathrm{g}$; Table 4) but the difference was not significant. Nevertheless, it could be hypothesized that the difference might appear significant on a larger number of samples. On the other hand, M. longissimus thoracis and rectus abdominis appeared less oxidative (COX and ICDH activities) than M. diaphragma; M. longus colli being in an intermediate position (Table 4). The difference in activities between M. longissimus thoracis and M. rectus abdominis was not significant but we confirmed previous results indicating that M. rectus abdominis is less glycolytic and more oxidative than M. longissimus thoracis [22] [24] [25]. In the present work, the differences in enzyme activities are not significant, probably because of the small cell sizes that may have limited the present results. It was previously indicated that gene encoding proteins involved in fast contraction and in glycolytic metabolism are under-expressed in $\mathrm{M}$. rectus abdominis in comparison to other muscles [26]. This could explain why higher oxidative and lower glycolytic metabolisms are noted in the present work for M. rectus abdominis than for M. longissimus thoracis even though the difference is not significant.

\subsection{Relationship between Grain Score and Muscle Characteristics}

It was previously indicated that all of the 10 carcasses were given a score of 3 for the EUROP fat grid and that the high variability of fat content between carcasses (Table 2) led to a non significant difference in intramuscular fat between the two grain-of-meat groups in any muscle $(p>0.10)$. This lack of difference makes it possible to compare all samples at equivalent lipid content levels (Table 3). When considering M. rectus abdominis and M. diaphragma together, the shear force needed to cut broiled meat was equivalent for samples from the coarse group and for those from the fine group (6.61 vs $6.29 \mathrm{~kg} ; p=0.5561)$. A significant difference was noted in raw meat with high differences between both grain groups (5.96 vs $5.10 \mathrm{~kg} ; p=0.0026$ ). This result confirmed the hypothesis that experts are able to assess different levels of hardness when scoring the carcasses for "grain of meat" [4] [8] [10]. Nevertheless, when evaluating results muscle by muscle, it appears that only shear force in broiled M. rectus abdominis is significantly different between the two groups ( $p=0.04$; Table 3 ). No significant difference was noted in M. diaphragma $(p=0.47)$. Thus, it appeared that muscle properties could not be extrapolated from one muscle of a carcass to another.

This difference between M. rectus abdominis and diaphragma could be due to muscle variability between the carcasses. It has been shown that there are large differences in primary fascicle size, perimysium thickness and the degree of associated adipose tissue among muscles [6].

The difference in shear force, all muscles taken together, may be linked to a slightly higher total collagen content (21.52 vs $19.31 \mathrm{mg} / \mathrm{g} \mathrm{DM}$; $p=0.0655)$ for the coarse group (Table 3). Nevertheless, the difference in collagen content was not significant in M. rectus abdominis, but this hypothesis might be supported by significant differences in collagen content both in M. diaphragma (27.94 vs $24.87 \mathrm{mg} / \mathrm{g} \mathrm{DM} ; p=0.02)$ and longissimus thoracis (15.86 vs $13.13 \mathrm{mg} / \mathrm{g} \mathrm{DM} ; p=0.03$ ). The lower collagen content in M. longissimus thoracis of the fine group confirms the scores given by the experts when evaluating the lack of visible nerves on this muscle ( $p$ $=0.005$; Table 2). Indeed, as previously indicated [11], the presence of nerves may be related to connective tissue content (correlation: -0.21 ) and collagen solubility (correlation: -0.36 ). Moreover, this result could be linked to 


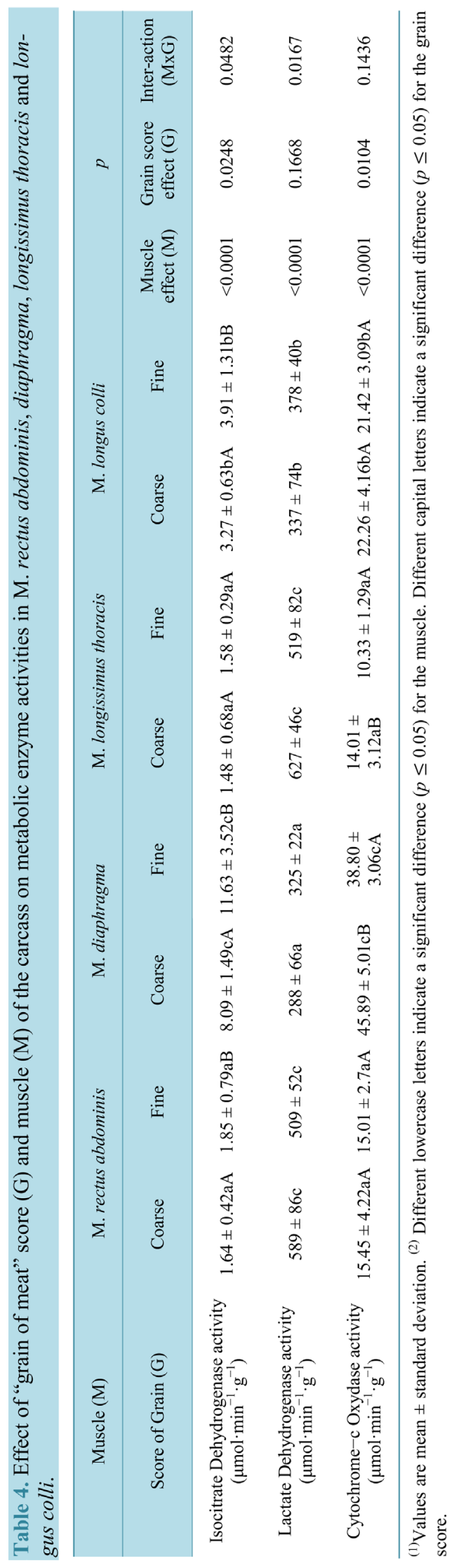


the conclusions of experts concerning the fine samples of M. longissimus thoracis which were found to be smoother and softer, with less hardness than those of the coarse group $(p<0.0001$; Table 2). The experts also noted a difference in the fiber types of $\mathrm{M}$. longus colli: those from the fine group were more crushable and flexible ( $p=0.02$ and 0.002 respectively) than those from the coarse group. The same difference was recorded by experts for fibers from M. diaphragma and longissimus thoracis, muscles from the fine group being both more crushable and more flexible than those from the coarse group.

This evaluation might be linked to a difference in collagen content, in favor of the fine group samples. Indeed, the negative relationship commonly agreed to exist between collagen content and tenderness [27] [28] argues for a higher tenderness in fine group muscles. Therefore, both M. diaphragma and longissimus thoracis could be used to predict the "grain of meat" score: low collagen content being indicators of fine grain of meat. Nevertheless, previous results indicated that for the M. longissimus thoracis, no significant relationship exists between grain of meat and either tenderness or shear force, or collagen content and collagen solubility [11]. According to Purslow [6], it appears that tenderness is partly correlated with fine grain (small diameters of muscle fascicle), but as is so common in meat science, this single variable is of extremely limited value in predicting the toughness of cooked meat, due to the highly multifactorial nature of texture.

The variability of the enzymatic activities from one muscle to another prevents us from handling the results for all muscles together. No difference was observed between groups for M. rectus abdominis and longus colli metabolisms either for oxidative or for glycolytic activities. In the M. diaphragma, which is well known for being very oxidative, only the Krebs circle enzyme cytochrome-c oxydase was found to be significantly different between groups, the $\mathrm{M}$. diaphragma being more oxidative in the coarse group ( $24.40 \mathrm{vs} 21.39 \mu \mathrm{mol} / \mathrm{min} / \mathrm{g}$; $p=$ 0.01). However, no significant difference appeared in ICDH oxidative enzyme activity, showing a variable reactivity of enzymes depending on their localization (Krebs cycle or respiratory chain). Indeed, ICDH enzyme activity was very variable in M. diaphragma (CV: $32 \%$ ), leading to a non-significant difference between the two groups. In the M. longissimus thoracis, which is both more glycolytic and more oxidative than the 3 other muscles, both oxidative and glycolytic metabolisms were found to be significantly more active in the coarse group than in the fine one.

According to the literature, in M. longissimus thoracis, M. semitendinosus and M. triceps brachii, tenderness scores increased and shear force on broiled meat decreased with muscle oxidative metabolism (MyHC I proportion and COX activity) [25]. The more oxidative muscles were of higher quality, particularly in terms of tenderness [27]. Moreover, some previous publications have indicated that muscles with a high proportion of slow oxidative fibers or a low proportion of fast glycolytic fibers are more tender [29]-[33]. On the contrary, in M. longissimus thoracis from the fine group, LDH activity is significantly lower than in the coarse group, arguing for a higher tenderness in fine group samples, a positive relationship existing between low glycolytic metabolism and high meat quality. Thus, differences in metabolism observed between the coarse and fine groups could not be used to explain tenderness variations among samples.

\section{Conclusion}

The present results lead us to conclude that it is difficult to identify a single muscle that can be relevant in the prediction of carcass meat quality. Indeed, as already indicated in the literature, the muscles studied did not all evolve in a similar way. Hammond [3], for example, previously found that thigh muscles with the highest rates of post-natal growth were felt to have the largest grain. So, it is undoubtedly utopian to believe that a single muscle can represent the whole carcass. Nevertheless, it should be emphasized that no conflicting conclusions were obtained from one muscle to another and that therefore the choice of a single muscle was feasible, the only possible bias being that not all of the muscles would respond with the same intensity depending on the physicochemical characteristic studied. In the present study, M. longus colli was examined in detail and scored by experts even though this muscle was not as easy to sample as the other muscles. Indeed, in many countries, the quartered carcasses are assessed and so the cross-section of the M. longissimus thoracis is easily viewed. So, even if the M. longus colli is scientifically interesting to study, it does not appear to have any practical application in many countries because it does not represent a sole determinant of a carcass. M. longissimus thoracis seems to be too tender as a muscle, and not an appropriate sample to distinguish fine and rough grains. It could be hypothesized that broiled M. rectus abdominis shear force is the best indicator of "grain of meat" and potential meat tenderness, as samples are tested by rheological analysis in the same way as meat samples are commonly eaten in France. 


\section{Conflicts of Interests}

The authors declare that there is no conflict of interests regarding the publication of this paper.

\section{Acknowledgements}

The authors wish to thank F. Delamarche, M. Jouanno and J. Lambert (technician at the AgroSup laboratory) for physicochemical measurements.

The work was carried out with the financial support of the Conseil Scientifique d'AgroSup and "ANRAgence Nationale de la Recherche-The French National Research Agency" under the "Programme Agriculture et Développement Durable”, project “ANR-05-PADD-012, Promotion du Développement Durable par les Indications Géographiques PRODDIG”.

\section{References}

[1] Bindon, B.M. and Jones, N.M. (2001) Cattle Supply, Production Systems and Market for Australian Beef. Australian Journal of Experimental Agriculture, 41, 861-877. http://dx.doi.org/10.1071/EA01052

[2] Boleman, S.J., Boleman, S.L., Miller, R.K., Taylor, J.F., Cross, H.R., Wheeler, T.L., Koohmaraie, M., Shackelford, S.D., Miller, M.F., West, R.L., Johnson, D.D. and Savell, J.W. (1997) Consumer Evaluation of Beef of Known Categories of Tenderness. Journal of Animal Science, 75, 1521-1524.

[3] Hammond, J. (1932) Growth and the Development of Mutton Qualities in the Sheep. Biological Monographs and Manuals (Vol. W), Oliver and Boyd, London.

[4] Delavigne, A.E. (2008) Le savoir faire des bouchers et des chevillards en matière de choix des animaux et des carcasses. Viande Produits Carnés Hors-Série, 26, 29-30.

[5] Taylor, R. (1998) Structural Basis for Meat Toughness and Tenderness. Polish Journal of Food and Nutrition Sciences, 7, 37-52.

[6] Purslow, P.P. (2005) Intramuscular Connective Tissue and Its Role in Meat Quality. Meat Science, 70, 435-447. http://dx.doi.org/10.1016/j.meatsci.2004.06.028

[7] Szczesniak, A.S. (1986) Sensory Texture Evaluation Methodology. In: Proceedings of the 39th American Meat Science Annual Meat Reciprocal Conference, National Livestock and Meat Board, Chicago, 86-95.

[8] Delavigne, A.E. (2008) Usage de la notion de "grain de viande” A propos d'un savoir-faire propre aux professionnels de la viande. Ethnozootechnie, 81, 67-77.

[9] Brady, D.E. (1937) A Study of the Factors Influencing Tenderness and Texture of Beef. Proceedings of the American Society of Animal Production, 30, 246-250.

[10] Oury, M.P., Dumont, R. and Durand, Y. (2008) Construction d'une grille de notation du grain de viande chez les bovins Charolais. Viande Produits Carnés Hors-Série, 26, 151-152.

[11] Ellies-Oury, M.P., Durand, Y., Delamarche, F., Jouanno, M., Lambert, J., Micol, D. and Dumont, R. (2013) Relationships between the Assessment of “Grain of Meat” and Meat Tenderness of Charolais Cattle. Meat Science, 93, 397-404. http://dx.doi.org/10.1016/j.meatsci.2012.11.001

[12] Oury, M.P. (2006) Eléments de différenciation de la qualité sensorielle des viandes liés aux pratiques d'élevage chez la génisse Charolaise. Thesis PhD, Université de Bourgogne, Dijon.

[13] NF 04-402 (1968) Viandes et produits à base de viande—Détermination de la teneur en matière grasse totale.

[14] Bergman, I. and Loxley, R. (1963) Two Improved and Simplified Methods for the Spectrophotometric Determination of Hydroxyproline. Analytical Chemistry, 35, 1961-1965. http://dx.doi.org/10.1021/ac60205a053

[15] Bonnet, M. and Kopp, J. (1992) Préparation des échantillons pour le dosage et la caractérisation qualitative du collagène musculaire. Viandes et Productions Carnés, 13, 87-91.

[16] Ansay, M. (1974) Individualité musculaire chez le bovin: Étude de l'équipement enzymatique de quelques muscles. Annales de Biologie Animale, Biochimie, Biophysique, 14, 471-486. http://dx.doi.org/10.1051/rnd:19740308

[17] Briand, M., Tamant, A., Briand, Y., Monin, G. and Durand, B. (1981) Metabolic Types of Muscle in the Sheep: I. Myosin ATPase Glycolytic and Mitochondrial Enzyme Activities. European Journal of Applied Physiology and Occupational Physiology, 46, 347-358. http://dx.doi.org/10.1007/BF00422122

[18] Piot, C., Veerkamp, J.H., Bauchart, D. and Hocquette, J.F. (1998) Contribution of Mitochondria and Peroxisomes to Plamitate Oxidation in Rat and Bovine Tissues. Comparative Biochemistry and Physiology, 121, 69-78.

[19] Salé, P. (1971) Evolution de quelques propriétés mécaniques du muscle pendant la maturation. Bulletin Technique 
C.R.Z.V. Theix, 6, 35-44.

[20] SAS Institude Inc. (2002) SAS User’s Guide, Statistics. Version 9.1, SAS Institute Inc., Cary.

[21] Belew, J.B., Brooks, J.C., McKenna, D.R. and Savell, J.W. (2003) Warner-Bratzler Shear Evaluation of 40 Bovine Muscles. Meat Science, 64, 507-512. http://dx.doi.org/10.1016/S0309-1740(02)00242-5

[22] Ouali, A., Sentendreu, M.A., Aubry, L., Boudjellal, A., Tassy, C., Geesink, G.H. and Farias-Maffet, G. (2005) Meat Toughness as Affected by Muscle Type. In: Hocquette, J.F. and Gigli, S., Eds., Indicators of Milk and Beef Quality, Wageningen Academic Publishers, Wageningen, 391-395.

[23] Brackebush, S.A., McKeith, F.K., Carr, T.R. and McLaren, D.G. (1991) Relationship between Longissimus Composition and the Composition of Other Major Muscles of the Beef Carcass. Journal of Animal Science, 69, 631-40.

[24] Bauchart, D., Durand, D., Gruffat-Mouty, D., Piot, C., Graulet, B., Chilliard, Y. and Hocquette, J.F. (1999) Transport sanguin et métabolisme tissulaire des lipides chez le veau de boucherie. Effets du remplacement du suif par de l'huile de coprah dans l'aliment d'allaitement. INRA Productions Animales, 12, 273-285.

[25] Oury, M.P., Dumont, R., Jurie, C., Hocquette, J.F. and Picard, B. (2010) Characterisation of Muscle Rectus Abdominis Muscular Fibres in Comparison to Muscle Longissimus Thoracis and Muscle Triceps Brachii of Charolais Cattle. BioMed Central Biochemistry, 11, 12.

[26] Cassar Malek, I., Ueda, Y., Bernard, C., Jurie, C., Sudre, K., Listrat, A., Barnola, I., Gentès, G., Leroux, C., Renand, G., Martin, P. and Hocquette, J.F., (2005) Molecular and Biochemical Muscle Characteristics of Charolais Bulls Divergently Selected for Muscle Growth. In: Hocquette, J.F. and Gigli, S., Eds., Indicators of Milk and Beef Quality, Wageningen Academic Publishers, Wageningen, 371-377.

[27] Renand, G., Picard, B., Touraille, C., Berge, P. and Lepetit, J. (2001) Relationships between Muscle Characteristics and Meat Quality Traits of Young Charolais Bulls. Meat Science, 59, 49-60. http://dx.doi.org/10.1016/S0309-1740(01)00051-1

[28] Rhee, M.S., Wheeler, T.L., Shackelford, S.D. and Koohmaraie, M. (2004) Variation in Palatability and Biochemical Traits within and among Eleven Beef Muscles. Journal of Animal Science, 82, 534-550.

[29] Ockerman, H.W., Jaworek, D., Van Stavern, B., Parrett, N. and Pierson, C.J. (1984) Castration and Sire Effects on Carcass Traits, Meat Palatability and Muscle Fiber Characteristics in Angus Cattle. Journal of Animal Science, 59, 981-990.

[30] Crouse, J.D., Koohmaraie, M. and Seideman, S.D. (1991) The Relationship of Muscle Fibre Size to Tenderness of Beef. Meat Science, 30, 295-302. http://dx.doi.org/10.1016/0309-1740(91)90039-S

[31] Strydom, P.E., Naude, R.T., Smith, M.F., Scholtz, M.M. and Van Wyk, J.B. (2000) Characterization of Indigenous African Cattle Breeds in Relation to Meat Quality Traits. Meat Science, 55, 79-88. http://dx.doi.org/10.1016/S0309-1740(99)00128-X

[32] Therkildsen, M., Melchior Larsen, L., Bang, H.G. and Vestergaard, M. (2002) Effect of Growth Rate on Tenderness Development and Final Tenderness of Meat from Friesian Calves. Animal Science, 74, 253-264.

[33] Dransfield, E., Martin, J.F., Bauchart, D., Abouelkaram, S., Lepetit, J., Culioli, J., Jurie, C. and Picard, B. (2003) Meat Quality and Composition of Three Muscles from French Cull Cows and Young Bulls. Animal Science, 76, 387-399. 